\title{
Analysis of the possibilities of using of DME fuel in motor boat drive systems
}

The characteristics of alternative fuel for diesel: dimethyl ether (DME) and an analysis of the potential to reduce emissions of toxic compounds by the engines when running on this fuel have been presented in this work. Basic types of design solutions of gas supply and control systems, possible for use in internal combustion engines with DME supply have been also presented. The paper presents a study of the legislation and an analysis of the feasibility of the system storage and fueling DME on board small vessels.

Key words: internal combustion engines, dimethyl-ether (DME), alternative fuel, emission reduction, fuel storage on board small vessels

\section{DME properties as a potential alternative fuel for CI engines}

Dimethyl ether (DME) is a chemical compound with a formula of $\mathrm{CH}_{3}-\mathrm{O}-\mathrm{CH}_{3}$. Under standard atmospheric conditions (0.1 MPa at $298 \mathrm{~K}$ ) DME is in gaseous state, it is invisible, non-toxic, odorless, environmentally benign and causes no negative health effects. When it is pressurized above $0.5 \mathrm{MPa}$ or cooled under $248 \mathrm{~K}\left(-25^{\circ} \mathrm{C}\right)$, it condenses to the liquid phase. The key properties of DME, in comparison to the diesel fuel are shown in Table 1.

Table 1. The key properties of DME [1, 6, 11, 13]

\begin{tabular}{|l|c|c|c|}
\hline Property (unit/condition) & Unit & DME & $\begin{array}{c}\text { Diesel } \\
\text { fuel }\end{array}$ \\
\hline Chemical structure & - & $\mathrm{CH}_{3}-\mathrm{O}-\mathrm{CH}_{3}$ & - \\
\hline Molar mass & $\mathrm{g} / \mathrm{mol}$ & 46 & 170 \\
\hline Carbon content mass & $\%$ & 52.2 & 86 \\
\hline Hydrogen content mass & $\%$ & 13 & 14 \\
\hline Oxygen content mass & $\%$ & 34.8 & 0 \\
\hline Carbon-to-hydrogen ratio & - & 0.337 & 0.516 \\
\hline Critical temperature & $\mathrm{K}$ & 400 & 708 \\
\hline Critical pressure & $\mathrm{MPa}$ & 5.37 & 3 \\
\hline Critical density & $\mathrm{kg} / \mathrm{m}^{3}$ & 259 & - \\
\hline Liquid density & $\mathrm{kg} / \mathrm{m}^{3}$ & 667 & 831 \\
\hline Relative gas density (air $=1)$ & - & 1.59 & - \\
\hline Cetane number & - & $>55$ & $40-50$ \\
\hline Auto-ignition temperature & $\mathrm{K}$ & 508 & 523 \\
\hline $\begin{array}{l}\text { Stoichiometric air/fuel mass } \\
\text { ratio }\end{array}$ & - & 9 & 14.6 \\
\hline Boiling point at 1 atm & $\mathrm{K}$ & 248.1 & $450-643$ \\
\hline Enthalpy of vaporization & $\mathrm{kJ} / \mathrm{kg}$ & 467.13 & 300 \\
\hline Lower heating value & $\mathrm{MJ} / \mathrm{kg}$ & 27.6 & 42.5 \\
\hline $\begin{array}{l}\text { Gaseous specific heat } \\
\text { capacity }\end{array}$ & $\mathrm{kJ} / \mathrm{kgK}$ & 2.99 & 1.7 \\
\hline Ignition limits vol. & $\% \mathrm{in}$ air & $3.4-17$ & $0.6-7.5$ \\
\hline Minimum ignition energy & $\mathrm{mJ}$ & 0.29 & - \\
\hline Kinematic viscosity of liquid & $\mathrm{cSt}$ & $<0.1$ & 3 \\
\hline Vapour pressure (at $298 \mathrm{~K}$ ) & $\mathrm{kPa}$ & 530 & 10 \\
\hline
\end{tabular}

Such properties as high cetane number and low autoignition temperature predestine DME to be an alternative fuel for CI engines (neat or mixed with other fuels). DME can be produced from natural gas, crude oil, residual oil, coal, waste products and biomass and may be considered as bio-fuel of second generation. There are two production methods of DME [7]:

- de-hydrogeneration of methanol,

- direct conversion from synthesis gas (syngas) which is a mixture of hydrogen $\left(\mathrm{H}_{2}\right)$, carbon monoxide $(\mathrm{CO})$ and carbon dioxide $\left(\mathrm{CO}_{2}\right)$.

The well-to-wheels energy efficiency of DME fueled vehicles is projected to be in the interval (19-22.5)\% [1]. This is comparable to compressed natural gas (CNG) fueled vehicles but less than in the case of direct injection (DI) diesels $(26 \%)$. Due to the low carbon to hydrogen ratio of the DME, the well-to wheel carbon dioxide $\left(\mathrm{CO}_{2}\right)$ emissions of DME fueled vehicles are comparable to those using DI diesels.

Advantages of DME fuel

- High oxygen content: together with the absence of C-C bonds in the molecules it is a cause for its practically smokeless combustion which is one of the most important advantages of DME.

- Low boiling point temperature: leads to quick evaporation when liquid-phase DME spray is injected into the engine cylinder.

- High latent heat of vaporization: reduces the $\mathrm{NO}_{\mathrm{x}}$ emissions due to the internal cooling of combustion chamber (injected liquid DME spray absorbs a lot of heat during evaporation process).

- High cetane number: results from the low auto-ignition temperature and almost instantaneous vaporization. The physical delay of DME is thus much shorter than in the case of conventional fuels. The chemical delay is also shorter, due to the smaller $\mathrm{C}-\mathrm{O}$ bond energy (359.0 $\mathrm{kJ} / \mathrm{mol}$ ) than that of the $\mathrm{C}-\mathrm{H}$ bond $(410.4 \mathrm{~kJ} / \mathrm{mol})$ [13].

- The purity: DME doesn't consists contaminations like sulphur and vanadium.

- Major benefit from this fuel is the big reduction of $\mathrm{CO}_{2}$ and $\mathrm{NO}_{\mathrm{x}}$ and the absence of $\mathrm{SO}_{\mathrm{x}}$.

- The minor pressure that is needed to liquidize DME: 5 bars is needed to liquidize and there is no cooling required. 
Disadvantages of DME fuel

- Low heating value: caused by the oxygen content in the molecules, it necessitates injected volume of DME be practically twice as large as in the case of diesel fuel (to deliver the same amount of energy).

- Low modulus of elasticity: the compressibility of DME is four to six time higher than that of diesel in a closed system (which means that the compression work of the high pressure fuel pump is 3.2 times greater [13]) and the compression work of the low pressure fuel pump for DME is greater by up to $10 \%$ in an open system [1].

- Lower viscosity than that of diesel fuel may cause leakage within the fuel supply system which relies on small clearances for sealing.

- Low lubricity can cause intensified surface wear of moving parts within the fuel injection system.

- High reactivity and corrosiveness: it is not compatible with most elastomers, the sealing can be achieved with inert material, such as teflon (PTFE).

- High vapor pressure: can be the cause of cavitation and erosion in the fuel system.

- DME can be toxic in great concentrations because it can block $\mathrm{O}_{2}$ from reaching the lungs, just like $\mathrm{CO}_{2}$.

\section{Engine performance and emissions characteristics with DME fuel}

\subsection{Particulate matter (PM) emission}

Soot is formed in fuel-rich regions (high equivalence ratio) under high temperature conditions (1500-2500 K). The precursors of soot are unsaturated hydrocarbons such as acetylene $\left(\mathrm{C}_{2} \mathrm{H}_{2}\right)$, ethylene $\left(\mathrm{C}_{2} \mathrm{H}_{4}\right)$ and propargyl $\left(\mathrm{C}_{3} \mathrm{H}_{3}\right)$. These soot precursors decrease with an increase in oxygen content and a decrease in direct $\mathrm{C}-\mathrm{C}$ bonds. It can be concluded that the soot formed in DME combustion should be almost zero at an oxygen content of $35 \%$ and no $\mathrm{C}-\mathrm{C}$ bonds. This implies that DME-fuelled engines would not need a particulate filter in the exhaust aftertreatment system. However, very small amounts of PM emissions are sometimes detected due to fuel additives used to improve lubrication, impurities in the fuel, or the engine lubrication oil.

\section{2. $\mathrm{NO}_{\mathrm{x}}$ emission}

Comparative values of $\mathrm{NO}_{\mathrm{x}}$ emissions from DME CI engines and those from diesel fuel vary depending on the engine conditions and the fuel supply system. Some studies found that $\mathrm{NO}_{\mathrm{x}}$ emissions are lower, while others reported the opposite $[4,17]$.

\section{Lower $\mathrm{NO}_{\mathrm{x}}$ emission}

Some researches reported that DME combustion results in lower $\mathrm{NO}_{\mathrm{x}}$ emissions $[5,10]$ than diesel combustion due to the lower heating value, the higher heat of vaporization, the shorter ignition delay, the smaller amount of fuel injected during the ignition delay period and the smaller amount of fuel burned during the premixed burning phase which results in the lower peak combustion temperature.

Higher $\mathrm{NO}_{\underline{x}}$ emission

It is possible that higher amount of $\mathrm{NO}_{\mathrm{x}}$ can be produced from DME than from diesel fuel for an early start of injection since the duration of the peak temperature would be longer in the initial combustion period due to shorter ignition delay of DME. When injection retardation is optimized for each fuel, $\mathrm{NO}_{\mathrm{x}}$ from $\mathrm{DME}$ is lower than from diesel fuel [1].

\subsection{HC and $\mathrm{CO}$ emission}

$\mathrm{HC}$ emissions from DME are usually lower or equal to those from the combustion of diesel fuel $[9,12,15]$. The over-reach and over-lean mixture regions, which the main source of unburnt hydrocarbons, may be smaller because DME has a short ignition delay period and $\mathrm{HC}$ emission can be reduced. DME is an oxygenated fuel containing $35 \%$ by mass of oxygen, has good mixing characteristics and is a superheated vapor after entering the combustion chamber. The volume of fuel-reach regions could thus be less, resulting in reduced $\mathrm{HC}$ emissions.

The data of $\mathrm{CO}$ emissions show some contradictions depending on the engine system and operating conditions. The higher $\mathrm{CO}$ emissions sometimes associated with DME could result from the longer injection duration, lower injection pressure and larger spray holes. The lower emissions of $\mathrm{CO}$ are linked to the structure of the DME molecule. The low $\mathrm{C} / \mathrm{H}$ ratio, the lack of $\mathrm{C}-\mathrm{C}$ bonds and the high oxygen content of the fuel should give faster and more effective oxidation of intermediate species. The $\mathrm{HC}$ and $\mathrm{CO}$ emissions could easily treated with an oxidation catalyst in the aftertreatment system.

\subsection{Non-regulated exhaust emissions}

Similarly to other oxygenated fuels, it is likely that some formaldehyde $\left(\mathrm{CH}_{2} \mathrm{O}\right)$ is formed during the combustion of DME in a $\mathrm{CI}$ engine. The formaldehyde emissions could be $1-10 \%$ of the non-methane hydrocarbon emissions, but can be reduced by oxidation catalyst to a negligible level.

\subsection{Combustion noise}

Since ignition delay is shorter for DME than for diesel, the pressure rise during the premixed burning stage is slower which results in reduced combustion noise.

\section{Basic types of design solutions of gas supply and control systems}

Closed pressurized fuel system are commonly in use: because of the low boiling point of DME $\left(248 \mathrm{~K}=-25^{\circ} \mathrm{C}\right)$, it is a gas under standard atmospheric conditions and therefore must be pressurized in a fuel system, including a storage tank and it is sold like a liquefied gas. Thus, the low boiling point of DME necessitates a closed pressurized fuel system. The vapor pressure of DME, roughly the same as LPG, demands the same kind of handling and storage considerations as for LPG.

The high vapor pressure of DME means that cavitation can take place, which in turn impedes stable fuel-injection operation. It is unavoidable in the fuel-injection equipment using higher pressure.

Although DME is kept in the liquid phase under atmospheric temperature conditions, when pressurized to above $0.5 \mathrm{MPa}$ the fuel-supply pressure (the feed pressure from the storage tank to the fuel pump) must be between 1.2 and $3 \mathrm{MPa}$ to avoid cavitation in the fuel line. This is 
not only because of the higher temperatures during engine operation, when the saturated vapor pressure of DME is higher, but also due to dynamic flow effects leading to the formation of vapor zones in the fuel line.

DME vaporizes immediately during injection, due to its low boiling point, even though it is injected as a liquid. Therefore, the high fuel injection pressures, such as 50-150 $\mathrm{MPa}$, used in modern diesel injection systems are not required for DME and there is a consensus that 20-30 MPa is sufficient as long as the required amount of DME can be supplied during the corresponding injection period even at high engine speeds.

Because of its low viscosity, currently available fuelinjection systems are not suitable for DME due to leakage problems. Even at atmospheric conditions the leakage of DME can be significant in regions of small clearance. In heavy-duty engines, leakage along the plungers is more serious than in light-duty engines, where the drive mechanism is engine-oil lubricated. To prevent this, most sealing material made of conventional elastomers should be replaced with anticorrosive material such as Teflon-coated o-rings or PTFE based high-tension sealing components.

Lower DME lubrication than diesel fuel results in wear problems. Lubrication can be improved using up to 2000 ppm of lubricant, e.g. Lubrizol (1000 ppm), Hitec 560 (100 ppm) and Infineum R655 (500 ppm), diesel fuel, dimethyl carbonate (DMC) and fatty acids [1]. The DME injection system is expected to operate at injection pressures not exceeding $30 \mathrm{MPa}$, while current diesel common rail systems are fitted to DME with lubrication additives at injection pressures up to $55 \mathrm{MPa}$.

The low liquid density and low calorific value require a higher volume of DME to be injected into the cylinder, compared with that for diesel fuel, 1.8 times the volume of diesel fuel is needed (to supply the same amount of energy), which causes a longer injection period.

The physical properties of DME, in comparison with diesel fuel, causes different characteristics of the needle lift of the injector, flow cavitation in the nozzle orifice was found to play a crucial role in the formation of the emerging from the nozzle spray. Initial tests showed that there can be expected a high rate of leakage of fuel past the nozzle plunger. To avoid leakage to the atmosphere the connection via by-pass return line to the pressurized fuel inlet to the pump can be used. In this way, leakage of DME past the nozzle remained liquefied and is returned to the inlet of the injection pump. A common rail fuel injection system is probably the best solution for a DME powered engines. AVL has developed such a system, which has leakage control with double seals and a purge system.

Two examples of the experimental DME fuel systems with direct injection have been presented subsequently in Fig. 1 and 2. The DME split injection strategy was applied in system presented in Fig. 2. The first DME injection starts at $100 \mathrm{CA}$ BTDC with a quantity of $2.5 \mathrm{mg} / \mathrm{cycle}$. The start of second DME injection is varied around TDC and its quantity was fixed at $1.8 \mathrm{mg} / \mathrm{cycle}$.

Two examples of the experimental DME fuel systems with indirect injection have been presented subsequently in Figs 3 and 4, subsequently with liquid injection before valves and vapor injection before valves. In system shown in Fig. 3 the intake air system should be to form an approximately homogeneous mixture of DME and air. DME would absorb much heat when it is gasified due to its high latent heat of evaporation. Thus an intake heating system must be used to maintain the intake temperature at a constant level.

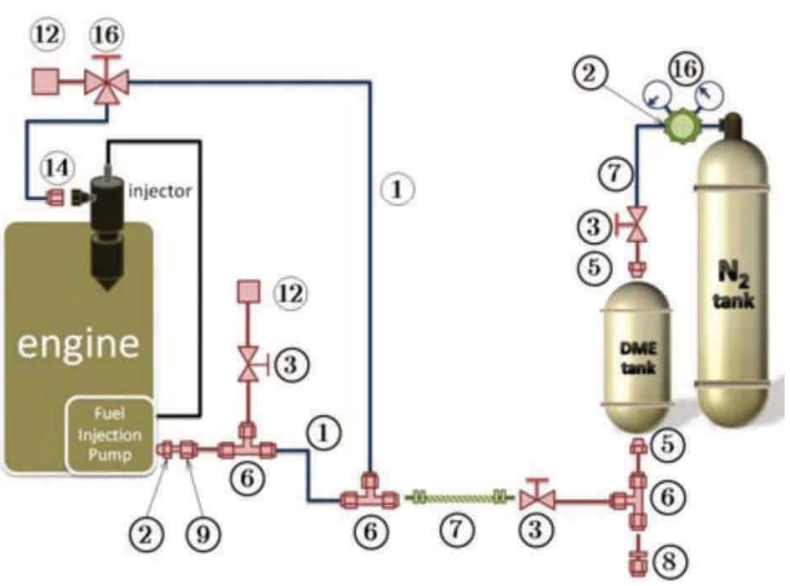

Fig. 1. High pressure direct injection engine test stand 1 - flexible Teflon hose tube adapter, 2 - male connector, 3 - ball valve, 5 - tube adapter, 7 flexible teflon hose tube adapter [16]

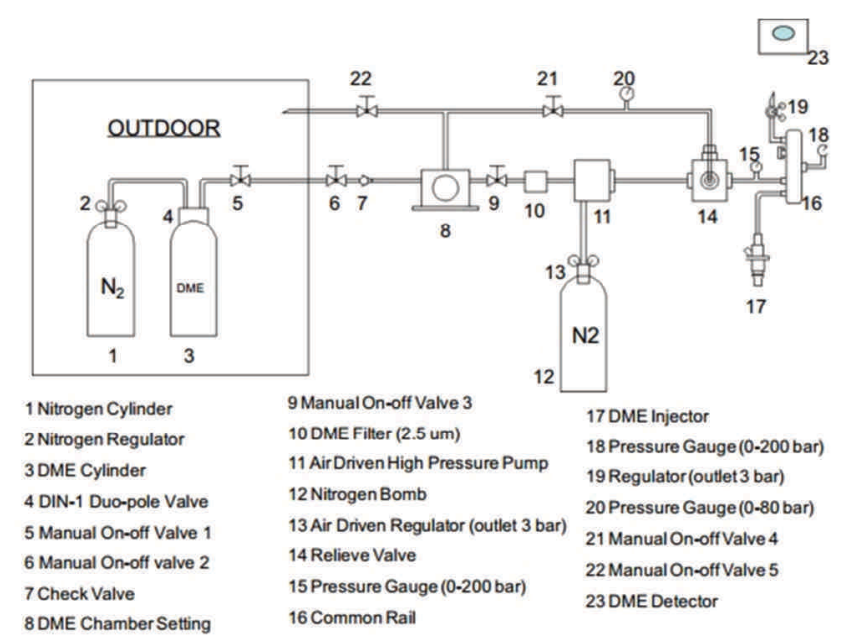

Fig. 2. Experimental test stand for DME direct injection [1]

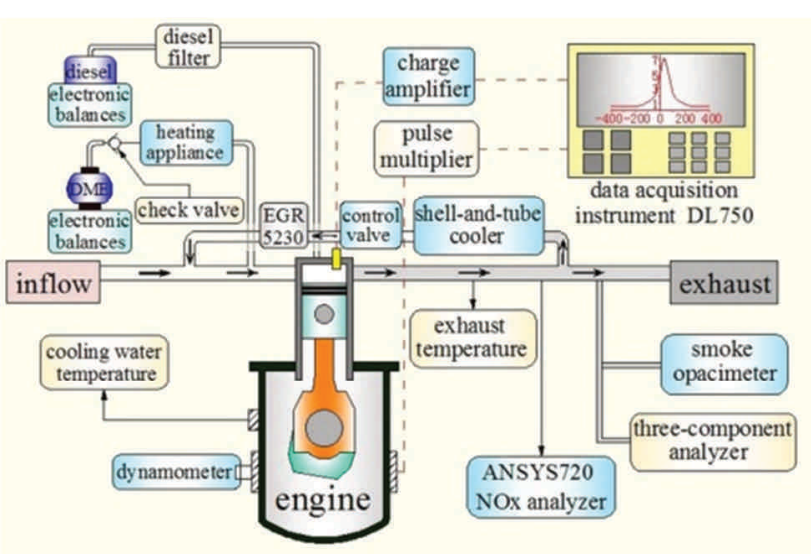

Fig. 3. Experimental DME fuel systems with indirect liquid injection before valves [18] 
Analysis of the possibilities of using of DME fuel in motor boat drive systems

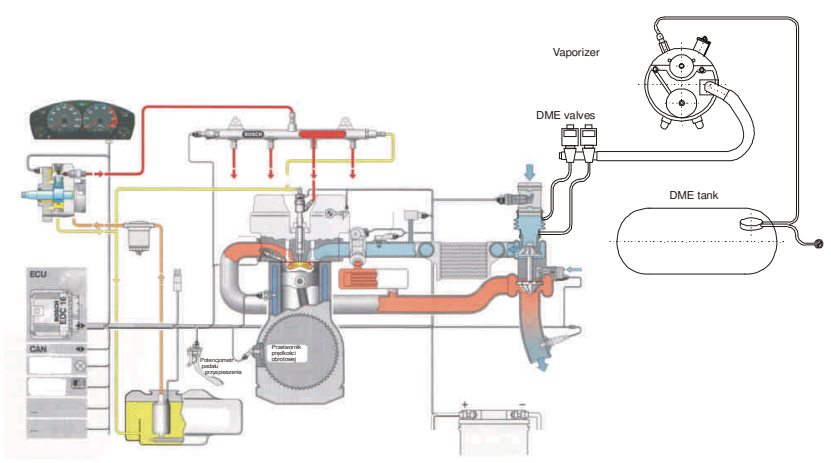

Fig. 4. DME vapor injection

\section{Analysis of the requirements for DME safe storage and fueling for vessels}

Ships and vessels are subject to the supervision of classification societies. From this reason all matters related to fuel storage and fueling (bunkering) are covered by appropriate rules published by classification societies. In Poland most of vessels, especially inland, are registered by Polish Ship Register. PRS has published following rules for small ships and vessels [14]:

- Rules for the Classification and Construction of Small Sea-going Ships;

- Rules for the Classification and Construction of High Speed Craft;

- Rules for the Classification and Construction of Inland Waterways Vessels;

- Rules for the Classification and Construction of Motor Boats.

Each of above publication include chapter related to Machinery and Piping Systems where all requirements related to fueling systems are described. Those are mainly general rules focused on marine fuels diesel and petroleum. For small ships and vessels gaseous fuels are still not popular, but for big cargo ships - especially gas carriers (LNG or CNG) technologies for engines fueling with gaseous fuels are very well known.

For those ships IMO, the International Maritime Organization which is the United Nations specialized agency with responsibility for the safety and security of shipping and the prevention of marine pollution by ships, has published International Code of Safety for Ship Using Gases or Other Low-flashpoint Fuels (IGF Code) [8]. This regulation is used as the base for all classification societies for new rules elaboration which cover all matters related to gaseous fuels on ships and vessels. IGF Code include all requirements related to usage both gaseous and liquefied gas fuels such as:

- ship/vessel design requirements,

- requirements for gas safe machinery space,

- requirements for ESD (Emergency Shut Down) protected machinery spaces,

- requirements for location and protection of fuel piping,

- liquefied gas fuel containment safety principles,

- design of barriers in relation to tank types,

- filling limit for liquefied gas fuel tanks,

- maintaining fuel storage condition.
The IGF Code is foreseen mostly for big marine ships and for small ships and boats can be used as reverence not as strict rules because the scale of fuel system complicity is quite different. Furthermore the IGF Code is mostly focused on CNG and LNG fuels whereas DME even if its theoretically covered by IGF but there is no strict rules for this particular fuel. That means that use IGF code for DME fueling systems, especially for small vessels, should be pointed mostly to maintain save conditions but some technical requirements could be not feasible for that kind of vessels.

DME is non-carcinogenic, degrades rapidly in the atmosphere and is not a global warming agent. Accidental spills cannot poison water. DME will not sink to the water and it is not absorbed by the soil. It is a gas in ambient conditions and requires a pressure of about 5 bar to stay liquefied, but does not require cryogenic storage. DME is not less safe than the conventional fuels like MGO and HFO. When a tank with DME catches fire, the pressure inside will rise. A safety valve will open and a flame will eject from the tank. The DME is instantly gas and is less harmful. When oil catches fire, it burns but it might explode also. Enough evidence can be found of cars that exploded during fire. This makes DME not necessarily less safe, despite the low flash temperature. This case is well known from automotive usage of LPG, which in case of storage is very similar to DME. Year of operation of cars fueled with LPG show that safe storage and engine fueling is technically well implemented and can be transferred for vessels and DME usage.

Properties of DME described in tab. 1 show that it behaves similar to propane. For that reason DME has more or less the same requirements for handling and storage precautions as LPG. It is stored and transported at ambient temperatures in tanks similar to those used in the propane industry. In terms of infrastructure availability, unlike CNG and LNG, the global propane infrastructure is robust, inexpensive and extensive. Hence, propane distributors can be used for transportation and storage of DME. Also form the point of view of small vessels on board DME fuel installation it will be more similar to propane handling fuel system (Fig. 5).

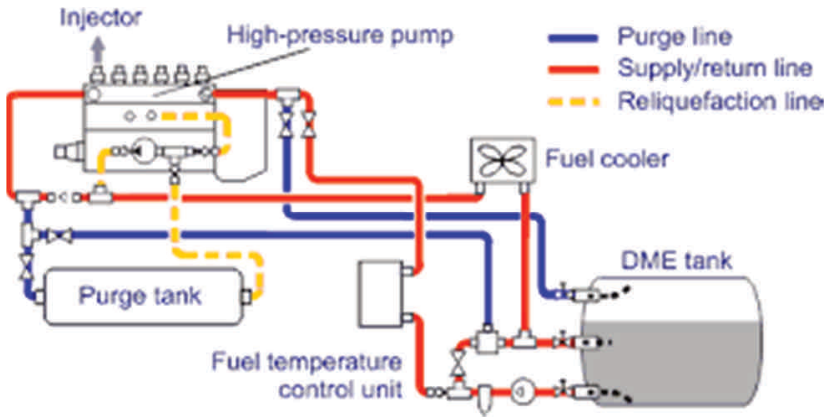

Fig. 5. Example of DME handling fuel system for small vessel [3]

LPG fuel which is very similar to DME is very well known from automotive industry. There are large number of installations for spark ignited engines and also for diesel engines (so called gasdiesel). So the technology is known and very well developed and it should not be very difficult 
to transfer knowledge and experience from automotive to marine installations. The biggest difference and also challenges are as follows:

- engineering - in case of regasification, the process needs heat to prevent pressure regulator blocking by frost. In case of outboard engines it is required to deliver the engine heat for cooling system to the pressure regulator. It can be also covered by electric heating system;

- refueling - for bigger vessels with bigger tanks refueling can take lot of time. For this case there should be investigated two possible solutions:

- development of high-speed filling equipment for DME with capacity of $\mathrm{min} .80 \mathrm{~L} / \mathrm{min}$ to be competitive against existing diesel oil filling speed,

- development of exchangeable DME storage tanks system;

- safety - in case of automotive applications any leakage of fuel cannot enter inside car because of the natural parameters of liquefied gas and due to the fact that whole fueling installation is located outside of the compartment with the driver and passengers. In case of ships/boats it is impossible to have all fueling system outside the hull. For that reason there is need for more investigation in relation between the real safety, IGF Code requirements and reasonable technical capabilities.

Gas cylinders are designed to be stored and operated in an upright position with their 'on cylinder' valve uppermost. To help prevent damage and leaks they should be kept and used in this way. If cylinders and their associated pipework and fittings can move about too much, those fittings, valves or regulators can quickly become damaged and leak. To reduce the risk of this happening, cylinders and their lockers must be securely stowed. It's recommended that cylinders, cylinder lockers or cylinder housings do not obstruct people moving around the deck or walkway, or interfere with the normal and safe operation of the boat. Cylinders are designed to release excess pressure that can build up if they're exposed to extreme heat. Under these circumstances, gas can quickly find its way into the interior of the boat presenting a significant and immediate risk of fire or explosion (Fig. 6). To minimize the risk of this happening cylinders, cylinder lockers or cylinder housings must not be located near to heat sources. In the event of a fire on board, which causes the cylinders to overheat, an explosion could occur or the cylinder could jet gas onto a fire. To give crew, or the emergency services, a chance to get to the cylinders to remove them they must be readily accessible and movable.

All gas fittings and components between the cylinder and the input side of the gas regulator (which is there to reduce the output pressure of the bottled gas) are classified as the 'high pressure' side of the gas system. Damage here could cause a very rapid and significant burst of gas. To reduce the chances of this gas reaching the interior of the boat the high pressure components must be installed in one of the following locations:

- on the open deck,

- on the cabin top,
- outside the cockpit,

- in a cylinder housing.

If two or more cylinders are used, each high pressure connection must be protected by a non-return valve. This will prevent a high pressure leak occurring when one of the two cylinders is disconnected.

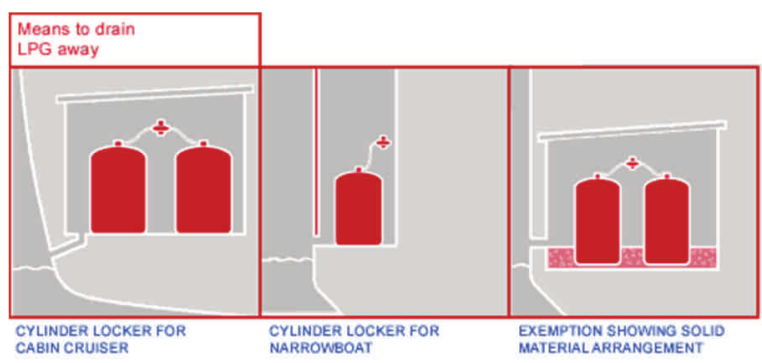

Fig. 6. Ways of draining of fuel leaks [2]

\section{Simulation of gas leaking diffusion from installation}

Using the computer program Fire Dynamics Simulator (FDS) ver. 6.5.3 the simulation of DME gas leaking diffusion from installation in a 15-meter sailing yacht the Voyager 495-2 has been made. The yacht is equipped with Diesel engine, placed in an engine compartment, which is ventilated by an exhaust fan with a capacity of $150 \mathrm{~m}^{3} / \mathrm{h}$. The scheme of the fuel supply system, in which the motor is equipped is shown in Fig. 4. In the simulation, two variants of leakage were assumed:

- variant I - small leakage due to imperfect installation assembly and faulty seals, leakage occurs in the form of gas, just after the reducer: $0.1 \mathrm{dm}^{3} / \mathrm{h}$;

- variant II - large leakage due to failure of the fuel delivery system, liquid leakage: $4.8 \mathrm{dm}^{3} / \mathrm{h}$.

Figure 7 shows a diagram of the engine compartment with the location of the leakage.

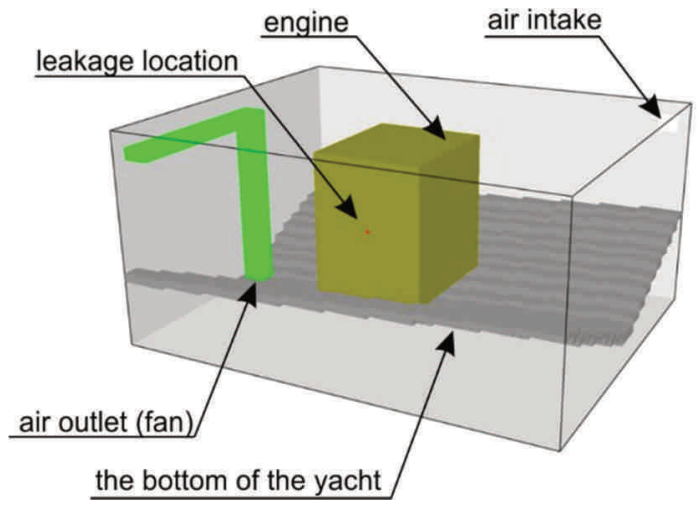

Fig. 7. Diagram of the engine compartment

The simulations concerned the first 120 seconds since gas leakage started. Figures 8 and 9 show the total mass of DME gas accumulated in the engine compartment, respectively for I and II leakage variant. For extrapolated results, the maximum average volumetric gas concentration in the air should not exceed, respectively for variant I and II: $1.90 \cdot 10^{-8} \%$ and $2.51 \cdot 10^{-04} \%$, and they are well below the ignition limit. 


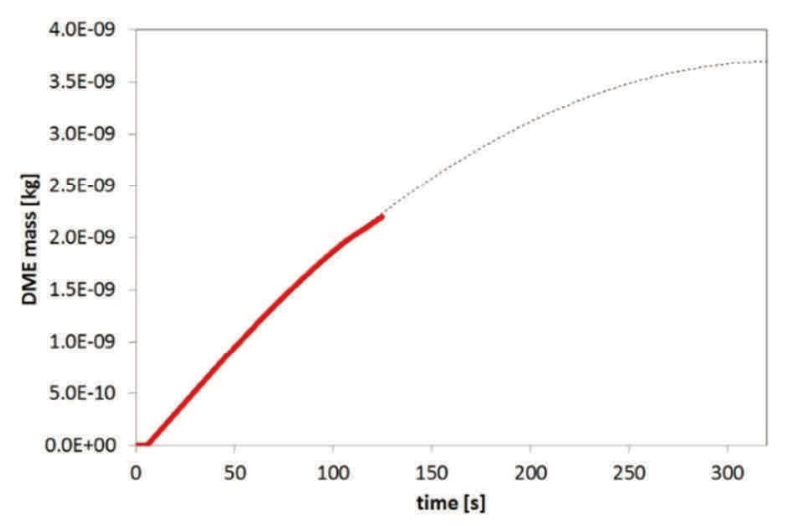

Fig. 8. DME gas accumulation in the engine compartment, leakage variant I

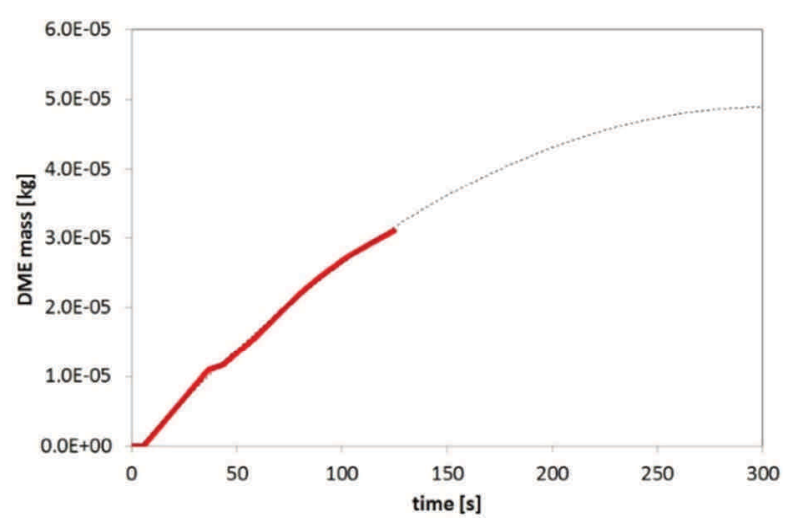

Fig. 9. DME gas accumulation in the engine compartment, leakage variant II

Locally, DME concentrations in the air can be significantly higher, but for the first 120 seconds of the test (Fig. 10 and 11), no dangerous levels were reached in any of the controlled sections.

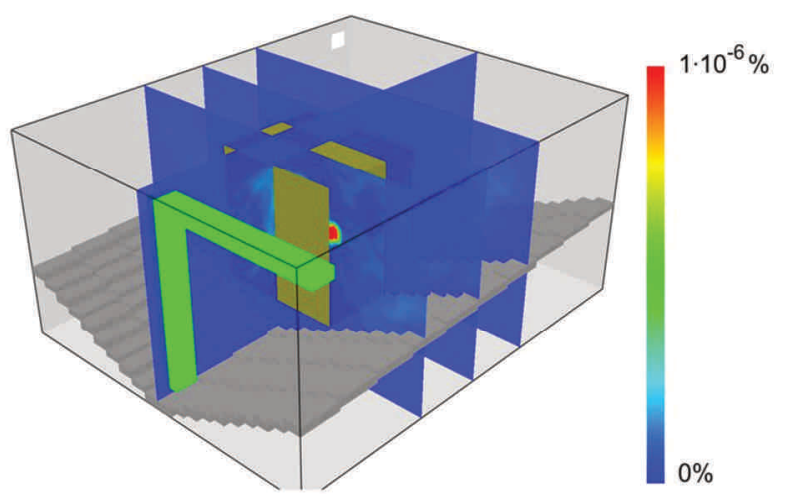

Fig. 10. DME volumetric concentration in the air, leakage variant I

\section{Bibliography}

[1] ARCOUMANIS, C. et al. The potential of di-methyl ether (DME) as an alternative fuel for compressed ignition engines: A review. Fuel. 2008, 87, 1014-1030.

[2] Boat Safety Scheme, www.boatsafetyscheme.org.

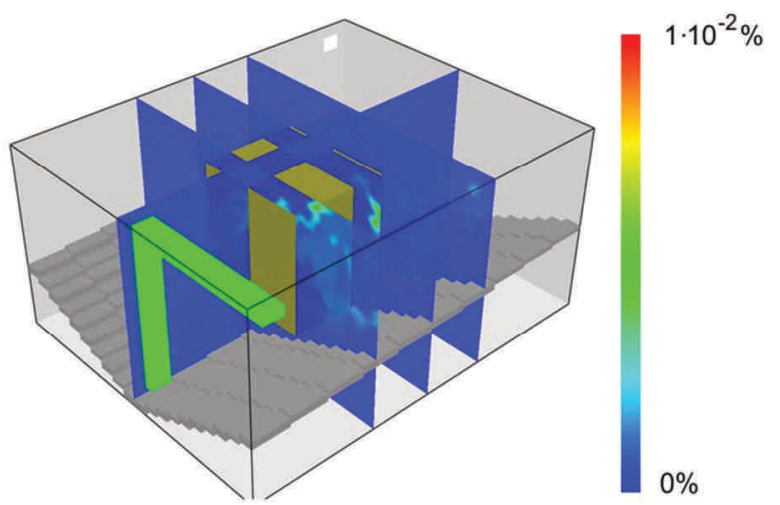

Fig. 11. DME volumetric concentration in the air, leakage variant II

Low concentrations of DME in the air result from the use of an efficient ventilation system for the engine compartment (Fig. 12).

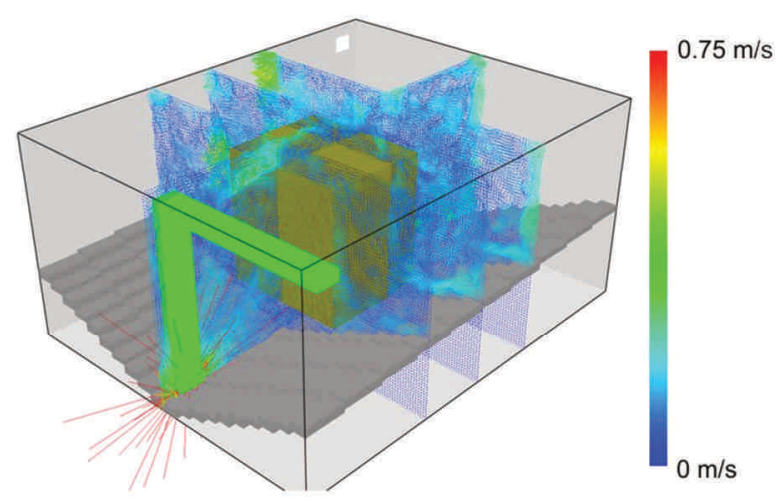

Fig. 12. Air velocity distribution in the engine compartment

\section{Summary}

From the environmental benefits point of view, DME is better than diesel fuel. The main advantage is a negligible level of PM emission. The $\mathrm{HC}$ and $\mathrm{CO}$ emissions are comparable to diesel-fueled engines. Unfortunately, the $\mathrm{NO}_{\mathrm{x}}$ emissions are also comparable and have to be treated similarly, i.e. with such methods as exhaust gas recirculation (EGR), urea-selective catalytic reduction (SCR) or lean $\mathrm{NO}_{\mathrm{x}}$ traps (LNT).

DME fueling systems for boats and vessels seems to be very perspective, especially from the environmental point of view. From technical point of view the fuel handling and storage system could be very similar to LPG systems very well-known from automotive industry.

Gas leakage simulations have shown that the use of a standard exhaust fan enables to keep low vacuum in the engine compartment. On the other hand, in case of leakage, the concentration of DME gas is kept much below the ignition limit. 
[5] FLEISCH, T.H., MEURER, C. DME, the diesel fuel for the 21st century? In: AVL conference engine and environment. 1995.

[6] FLEKIEWICZ, M., FABIŚ, P. Ocena wpływu mieszaniny DME i LPG na osiągi silnika ZI. Zeszyty Naukowe Politechniki Śląskiej, Seria: Transport. 2013, 81 Z, 31-44.

[7] IDZIOR, M., KARPIUK, W., SMOLEC, R. Eter dimetylowy jako nowoczesne paliwo alternatywne drugiej generacji do zasilania współczesnych silników o zapłonie samoczynnym. Logistyka. 2015, 3, 1836-1845.

[8] IGF Code 2016 Edition Published by IMO, www.imo.org.

[9] ISHIDA, M., JUNG, S., UEKI, H., SAKAGUCHI, D. Combustion of premixed DME and natural gas in a HCCI engine. Combustion Engines. 2005, 121(2), 20-29.

[10] KAPUS, P., OFNER, H. Development of fuel injection equipment and combustion system for DI diesels operated on di-methyl ether. SAE Technical Paper. 1995, 950062.

[11] MOIRANGTHEM, K. Alternative fuels for marine and inland waterways. JRC Technical Reports. 2016.

[12] PARK, S. Optimization of combustion chamber geometry and engine operating conditions for compression ignition engines fueled with dimethyl ether. Fuel. 2012, 97, 61-71.
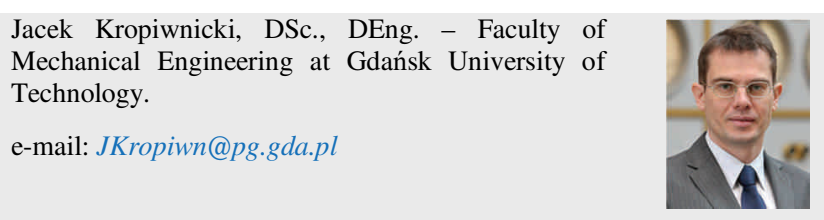

Zbigniew Kneba, DSc., DEng. - Faculty of Mechanical Engineering at Gdańsk University of Technology.

e-mail: ZKneba@pg.gda.pl

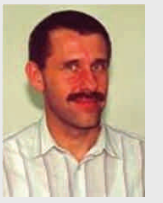

Prof. Janusz T., Cieśliński, DSc., DEng. - Faculty of Mechanical Engineering at Gdańsk University of Technology.

e-mail: JCieslin@pg.gda.pl
[13] PARK, S.H., LEE, C.S. Applicability of dimethyl ether (DME) in a compression ignition engine as an alternative fuel. Energy Conversion and Management. 2014, 86, 848863.

[14] PRS rules and publications - classification rules, www.prs.pl/ prs-rules-and-publications/classification-rules.html.

[15] THOMAS, G., FENG, B., VEERARAGAVAN, A. et al. Emissions from DME combustion in diesel engines and their implications on meeting future emission norms: A review. Fuel Processing Technology. 2014, 119, 286-304.

[16] WATTANAVICHIEN, K. Implementation of DME in a small direct injection diesel engine. International Journal of Renewable Energy. 2009, 4(2), 1-12.

[17] ZHANG, H.F., SEO, K., ZHAO, H. Combustion and emission analysis of the direct DME injection enabled and controlled auto-ignition gasoline combustion engine operation. Fuel. 2013, 107, 800-814.

[18] ZHAO, Y., WANG, Y., LI, D. et al. Combustion and emission characteristics of a DME (dimethyl ether)- diesel dual fuel premixed charge compression ignition engine with EGR (exhaust gas recirculation). Energy. 2014, 72, 608-617.

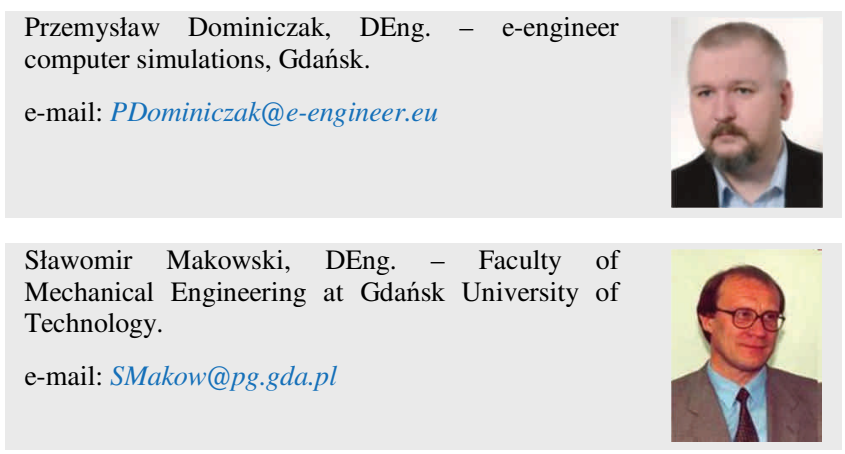

Maciej Ziółkowski, DEng. - Faculty of Mechanical Engineering at Gdańsk University of Technology.

e-mail:Maciej.Ziolkowski@pg.gda.pl
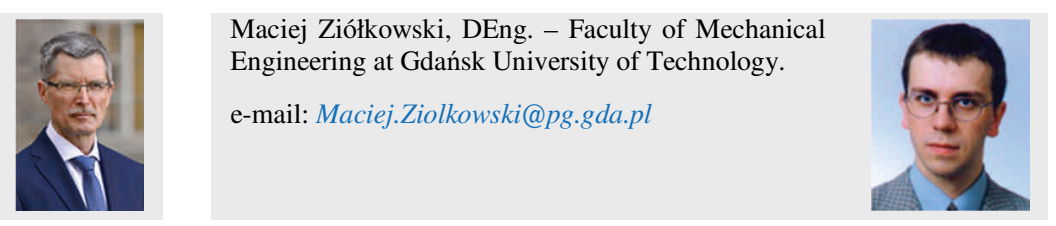